\title{
EFEKTIVITAS TERAPI BEKAM PADA PASIEN DENGAN NYERI PUNGGUNG BAWAH: LITERATUR REVIEW
}

\author{
Rika Oktaviani Anshori ${ }^{1}$, Tia Bella Sunari ${ }^{2}$, Wildatus Sholeha ${ }^{3}$, Rohayati $^{4^{*}}$ \\ 1. Program Studi S1 Keperawatan, STIKes Mitra Keluarga, Bekasi-Indonesia \\ 2. Program Studi S1 Keperawatan, STIKes Mitra Keluarga, Bekasi-Indonesia \\ 3. Program Studi S1 Keperawatan, STIKes Mitra Keluarga, Bekasi-Indonesia \\ 4. Program Studi Pendidikan Profesi Ners, STIKes Mitra Keluarga, Bekasi-Indonesia
}

*Korespondensi: Rohayati |STIKes Mitra Keluarga | athearobiansyah@ gmail.com

\begin{abstract}
Abstrak
Pendahuluan: Nyeri punggung bawah dan nyeri leher merupakan suatu gejala yang memberikan dampak yang cukup besar dalam aktivitas gerak seseorang. Nyeri punggung bawah dan nyeri leher dapat diatasi dengan terapi bekam. Terapi bekam merupakan bagian dari terapi komplementer yang dilakukan melalui prosedur penghisapan kulit dengan melakukan penyayatan sehingga mengeluarkan darah dari permukaan kulit lalu ditampung di dalam gelas dengan cara disedot menggunakan gelas atau vakum modern yang bersih dan steril. Tujuan penulisan ini adalah untuk mengetahui efektifitas terapi bekam dalam mengurangi nyeri punggung bawah dan nyeri leher.

Metode: Metode yang digunakan adalah pendekatan sederhana terhadap 6 artikel tentang bekam bagi pasien dalam periode 2016-2020.

Hasil: Hasil yang didapatkan adalah dalam beberapa penelitian membuktikan penggunaan terapi bekam (cupping) memiliki efek positif yaitu dapat mengurangi skala nyeri dan nyeri punggung bawah non-spesifik.

Kesimpulan: Kurangnya penelitian yang ada di Indonesia tentang terapi bekam menjadi tantangan bagi perawat dan perawat diharapkan menekuni terapi bekam karena dapat memberikan banyak manfaat.
\end{abstract}

Kata Kunci: Terapi bekam, Bekam basah, Nyeri punggung belakang, Nyeri leher.

Diterima 12 Januari 2021; Accepted 30 Juni 2021

\section{PENDAHULUAN}

Nyeri punggung bawah saat ini menjadi penyebab utama timbulnya kecacatan. Nyeri punggung bawah merupakan suatu gejala bukan penyakit yang disebabkan karena beberapa kelainan atau penyakit baik yang diketahui maupun tidak diketahui. Nyeri ini biasanya terjadi pada daerah tulang rusuk bawah dan lipatan bokong. Sumber rasa nyeri pada punggung bawah tidak bisa diidentifikasi secara akurat. Namun hal ini dapat dilihat dari hasil pencitraan menggunakan radiografi, CT scan, dan MRI (Hartvigsen et al., 2018). Selain itu, nyeri punggung bawah dapat memberikan dampak yang signifikan terhadap kapasitas fungsional tubuh, karena rasa nyeri akan membatasi aktivitas gerak (Allegri et al., 2016).

Prevalensi nyeri punggung bawah sekitar 4,3\% pada rentang usia 24 s.d 39 tahun meningkat menjadi 19,6\% pada rentang usia 20 s.d 39 tahun (Meucci, Fassa, \& Xavier Faria, 2015). Rerata prevalensi global LBP adalah 7,50\% pada tahun 2017. Rerata prevalensi LBP Kawasan Asia Tenggara adalah 7,08\% (Wu et al., 2020). Prevalensi nyeri leher sekitar 20,3\% (Genebra, Maciel, Bento, Simeão, \& Vitta, 2017).

Nyeri punggung bawah dan nyeri leher dapat ditangani dengan penatalaksanaan keperawatan mandiri secara non-farmakologis berupa terapi komplementer (Lindquist, Tracy, \& Snyder, 2018). Terapi komplementer merupakan pengobatan holistik yang menggabungkan terapi tradisional dengan terapi modern. Salah satu terapi komplementer yang sudah lama digunakan yaitu bekam atau cupping. Bekam merupakan suatu keadaan dimana terjadi penghisapan kulit dengan melakukan penyayatan, sehingga mengeluarkan darah dari permukaan kulit, lalu ditampung didalam gelas. Bekam juga merupakan metode untuk pembersihan darah dengan mengeluarkan sisa toksin dari dalam tubuh melalui kulit dengan cara disedot menggunakan gelas atau vakum modern yang bersih dan steril. Bekam terbagi menjadi 2 jenis, yaitu bekam basah dan bekam kering (Righo, A., \& Ronas, M. R., 2014). Komplikasi yang kemungkinan terjadi setelah dilakukan terapi bekam yaitu munculnya abses, hematoma, infeksi kulit, jaringan parut, kelelahan, luka bakar, mual, pusing, rasa gatal, dan sakit kepala (Cao, Han, Zhu, \& Liu, 2015).

Nyeri punggung yang dapat dikurangi dengan bekam yaitu nyeri punggung bawah kronis (Teut et al., 2018). Bekam dapat efektif pada pasien nyeri punggung bawah setelah 4 minggu pengobatan (Chi et al., 2016). 
Peran perawat dalam memberikan terapi komplementer di antaranya sebagai konselor, pendidikan kesehatan, peneliti, pemberi pelayanan langsung, koordinator dan sebagai advokat. (Rajin, M., 2020). Wewenang perawat dalam memberikan terapi komplementer dan alternatif tidak terlepas dari kultur budaya dan sumber daya alam di Indonesia yang merupakan negara yang memiliki berbagai macam kepercayaan, budaya dan kaya dengan tanaman obat yang bisa digunakan dalam pengobatan.

\section{METODE}

Penulisan literature review dilakukan melalui penelusuran database jurnal yaitu PubMed, Google Scholar, ACM Dl digital library, dan ScienceDirect. Kata kunci yang digunakan adalah "Cupping Therapy", "Reduce Pain", "Randomized Controlled Trial OR Case Study OR Cross Sectional”. Kriteria inklusi yang ditetapkan yaitu artikel membahas penelitian mengenai terapi bekam dalam mengurangi nyeri punggung bawah atau nyeri leher, artikel dalam 5 tahun terakhir (2015-2020), kriteria eksklusi yang dipergunakan adalah artikel terapi bekam bukan untuk mengurangi nyeri punggung bawah atau nyeri leher, artikel bukan berbahasa Inggris. Jumlah artikel yang ditemukan pada skrining awal sebanyak 10 artikel. Setelah dilakukan skrining, jumlah artikel akhir yang direview adalah 6 artikel.

\section{HASIL}

Terapi bekam memberikan banyak manfaat kepada penggunanya salah satunya dapat mengurangi intensitas nyeri. Hal ini dibuktikan dari beberapa penelitian yang menyampaikan bahwa penggunaan bekam dapat menurunkan skala nyeri pada penggunanya. Dalam studi literatur ini, penulis mengumpulkan 6 artikel yang berkaitan dengan penggunaan terapi bekam dalam membantu mengurangi intensitas nyeri. Artikel diambil dari beberapa sumber jurnal dalam periode 5 tahun terakhir (2015-2020). Hasil yang didapatkan adalah:

Tabel 1 : Hasil Penelitian

\begin{tabular}{|c|c|c|c|c|c|}
\hline No & $\begin{array}{c}\text { Nama } \\
\text { penulis } \\
\text { dan } \\
\text { tahun } \\
\text { terbit }\end{array}$ & $\begin{array}{c}\text { Desain } \\
\text { penelitia } \\
\mathbf{n}\end{array}$ & $\begin{array}{c}\text { Populasi dan } \\
\text { sampel }\end{array}$ & Prosedur intervensi & Ringkasan hasil \\
\hline 1 & $\begin{array}{c}\text { (de } \\
\text { Almeida } \\
\text { Silva, } \\
\text { Saragiotto } \\
\text {, Silva, de } \\
\text { Almeida } \\
\text { Lins, \& de } \\
\text { Souza, } \\
\text { 2019) }\end{array}$ & $\begin{array}{c}\text { A } \\
\text { double- } \\
\text { blind, } \\
\text { placebo- } \\
\text { controlle } \\
\quad d \\
\text { randomis } \\
\text { ed } \\
\text { clinical } \\
\text { trial }\end{array}$ & $\begin{array}{c}\text { Populasinya } \\
\text { merupakan individu } \\
\text { yang memiliki skala } \\
\text { nyeri dari } 3 \text { hingga } 8 \\
\text { dan nyeri punggung } \\
\text { bawah non-spesifik } \\
\text { selama lebih dari } 3 \\
\text { bulan. Jumlah } \\
\text { partisipan sebanyak } \\
90 \text { orang termasuk } \\
\text { laki-laki dan } \\
\text { perempuan yang } \\
\text { berusia 18-59 tahun. } \\
\text { Teknik } \\
\text { pengumpulan } \\
\text { sampel } \\
\text { menggunakan daftar } \\
\text { tunggu dari pasien } \\
\text { sekolah fisioterapi } \\
\text { klinik }\end{array}$ & $\begin{array}{l}\text { Kelompok terapi bekam kering } \\
\text { (kelompok intevensi) memperoleh } \\
\text { aplikasi terapi bekam kering dengan } \\
\text { dua hisap. Peserta kelompok } \\
\text { intervensi akan mendapatkan } \\
\text { aplikasi terapi bekam kering dengan } \\
\text { dua buah akrilik ukuran } 1 \text { cangkir } \\
\text { (diameter dalam } 4,5 \mathrm{~cm} \text { ) dengan } \\
\text { jarak masing-masing cangkir } 3 \mathrm{~cm} \text {, } \\
\text { secara bilateral sejajar dengan L1 - } \\
\text { L5 vertebra. Kelompok ini } \\
\text { menjalani terapi bekam kering } \\
\text { dengan dua hisap selama } 10 \text { menit, } \\
\text { seminggu sekali, selama } 8 \text { minggu } \\
\text { Kelompok plasebo (kelompok } \\
\text { placebo) memperoleh aplikasi terapi } \\
\text { bekam kering plasebo. Kelompok } \\
\text { plasebo akan menerima aplikasi } \\
\text { terapi bekam kering dengan dua } \\
\text { gelas akrilik tipe } 1 \text { (diameter dalam } \\
4,5 \text { cm) dengan jarak } 3 \text { cm antara } \\
\text { masing-masing cangkir, sejajar } \\
\text { bilateral dengan L1 - L5 vertebra } \\
\text { (gambar } 4 \text { ). Kelompok ini akan } \\
\text { menerima terapi bekam kering }\end{array}$ & $\begin{array}{c}\text { Penelitian ini } \\
\text { diharapkan } \\
\text { menunjukkan efek } \\
\text { baik jangka pendek, } \\
\text { jangka menengah } \\
\text { maupun jangka } \\
\text { Panjang dalam } \\
\text { mengurangi nyeri } \\
\text { punggung bawah } \\
\text { kronik. Namun karena } \\
\text { penelitian ini } \\
\text { merupakan protokol, } \\
\text { penulis tidak } \\
\text { menggambarkan hasil } \\
\text { uji statistic yang } \\
\text { menggambarkan } \\
\text { efektifitas yang } \\
\text { diharapkan. }\end{array}$ \\
\hline
\end{tabular}


plasebo selama 10 menit, 1 kali seminggu, selama 8 minggu.

Namun, cangkir akan disiapkan

dengan lubang kecil berdiameter $<2$ mm untuk melepaskan tekanan negatif dalam hitungan detik. Pita perekat dua sisi akan digunakan agar kaca tidak jatuh dan kehilangan kontak dengan kulit

\begin{tabular}{|c|c|c|c|c|c|}
\hline 2 & $\begin{array}{c}\text { (Teut et } \\
\text { al., 2016) }\end{array}$ & $\begin{array}{l}\text { Randomi } \\
\text { zed } \\
\text { controlle } \\
\text { d trial }\end{array}$ & $\begin{array}{c}\text { Pasien laki-laki dan } \\
\text { perempuan rentang } \\
\text { usia } 18 \text { tahun - } \\
65 \text { tahun dengan } \\
\text { diagnosis klinis } \\
\text { chronic low back } \\
\text { pain (cLBP) non } \\
\text { spesifik. Jumlah } \\
\text { total responden } \\
\text { adalah } 110 \text { orang } \\
\text { terbagi ke dalam } \\
\text { tiga kelompok yaitu } \\
37 \text { orang kelompok } \\
\text { bekam regular } \\
\text { pulsatile dengan } \\
\text { pemberian } \\
\text { parasetamol bila } \\
\text { dibutuhkan ( } 8 \text { kali), } \\
36 \text { orang kelompok } \\
\text { bekam minimal } \\
\text { dengan pemberian } \\
\text { parasetamol bila } \\
\text { dibutuhkan ( } 8 \text { kali) } \\
\text { dan } 37 \text { orang } \\
\text { dengan kelompok } \\
\text { control dengan } \\
\text { pemberian } \\
\text { parasetamol bila } \\
\text { diperlukan. }\end{array}$ & $\begin{array}{l}\text { Peserta diacak ke kelompok bekam } \\
\text { pulsatile menerima } 8 \text { sesi bekam } \\
\text { (masing-masing } 8 \text { menit dalam } 4 \\
\text { Minggu dengan perangkat Cupping } \\
\text { pulsatile HeVaTech PST } 30 \text { dan } \\
\text { tekanan negative antara-150 hingga } \\
\text {-350 mbar) dan hisap interval } 2 \\
\text { detik diterapkan ke area punggung } \\
\text { bawah. } \\
\text { Peserta diacak menjadi kelompok } \\
\text { bekam menerima } 8 \text { sesi bekam } \\
\text { (masing-masing } 8 \text { menit) dalam } 4 \\
\text { Minggu dengan perangkat Cupping } \\
\text { pulsatile HeVeaTech PST } 30 \text { dan } \\
\text { dua cangkir silikon dan tekanan } \\
\text { negatif yang lebih lemah di sekitar - } \\
70 \text { mbar dan interval hisap } 2 \text { detik. }\end{array}$ & $\begin{array}{c}\text { Hasil menunjukkan } \\
\text { bahwa bekam regular } \\
\text { pulsatile }((21.2(12.2 ; \\
30.1) ; p<0.001) \text { dan } \\
\text { bekam minimal }(15.7 \\
(6.9 ; 4.4) ; p=0.001) \\
\text { efektif dalam } \\
\text { mengurangi keluhan } \\
\text { cLBP setelah } 4 \\
\text { minggu intervensi } \\
\text { dibandingkan dengan } \\
\text { kelompok control. } \\
\text { Pada intervensi } \\
\text { minggu ke-12 hanya } \\
\text { bekam regular } \\
\text { pulsatile yang } \\
\text { menunjukkan efek } \\
\text { signifikan dalam } \\
\text { menurunkan cLBP } \\
\text { ((3.1; } \\
\text { 27.1); } p=0.014) .\end{array}$ \\
\hline 3 & $\begin{array}{c}\text { (Chi et al., } \\
2016)\end{array}$ & $\begin{array}{l}\text { Randomi } \\
\text { zed } \\
\text { controlle } \\
\text { d trial } \\
\text { with } \\
\text { single } \\
\text { blind }\end{array}$ & $\begin{array}{l}\text { Jumlah responden } \\
\text { adalah } 27 \text { orang } \\
\text { untuk kelompok } \\
\text { intervensi dan } 27 \\
\text { orang untuk } \\
\text { kelompok control. } \\
\text { Responden terdiri } \\
\text { dari laki-laki (5 } \\
\text { orang) dan } \\
\text { perempuan (55 } \\
\text { orang) dengan } \\
\text { rentang usia } 24 \\
\text { hingga } 61 \text { tahun. } \\
\text { Pengelompokan } \\
\text { responden dipilih } \\
\text { secara acak dengan } \\
\text { metode urut dalam } \\
\text { amplop yang diberi } \\
\text { label "kelompok } \\
\text { bekam" } \\
\text { atau "kelompok }\end{array}$ & $\begin{array}{l}\text { Kelompok bekam menerima } \\
\text { Cupping Therapy api pada tiga titik } \\
\text { akupunktur, SI 15, GB 21, dan LI } \\
\text { 15. Cawan kaca ukuran sedang } \\
\text { dengan diameter } 4 \mathrm{~cm} \text { dan volume } \\
\text { 260mL (Cosmos International } \\
\text { Supplies Co., Ltd., Taiwan) } \\
\text { digunakan. Peserta diminta duduk } \\
\text { dengan nyaman di kursi dengan } \\
\text { kedua kaki rata di lantai dan } \\
\text { memperlihatkan area leher dan } \\
\text { bahu. } \\
\text { Prosedur bekam adalah sebagai } \\
\text { berikut: } \\
\text { Kapas alkohol dinyalakan } \\
\text { 1. } \\
\text { Kapas yang terbakar dengan cepat } \\
\text { ditempatkan di dalam cangkir dan } \\
\text { ditarik } \\
\text { Cangkir diletakkan di atas tiga titik } \\
\text { akupunktur, cangkir itu kemudian } \\
\text { dihapus setelah } 10 \text { menit, dan proses }\end{array}$ & $\begin{array}{c}\text { Hasil penelitian } \\
\text { menunjukkan bahwa } \\
\text { skin surface } \\
\text { temperature (SST) } \\
\text { pada titik akupunkture } \\
\text { GB } 21 \text { meningkat dari } \\
30.6^{\circ} \mathrm{C} \text { menjadi } \\
32.7^{\circ} \mathrm{C} \text { pada kelompok } \\
\text { intervensi and } \\
\text { menurun } 30.7^{\circ} \mathrm{C} \\
\text { menjadi } 30.6^{\circ} \mathrm{C} \text { pada } \\
\text { kelompok control. } \\
\text { Skore Neck pain } \\
\text { intensity (NPI) } \\
\text { berkurang dari } 9.7 \\
\text { menjadi } 3.6 \text { pada } \\
\text { kelompok intervensi } \\
\text { dan menurun dari } 9.7 \\
\text { menjadi } 9.5 \text { pada } \\
\text { kelompok kontrol. } \\
\text { SST dan NPI berbeda }\end{array}$ \\
\hline
\end{tabular}




\begin{tabular}{|c|c|c|c|}
\hline & & & $\begin{array}{c}\text { kontrol". } \\
.\end{array}$ \\
\hline 4 & $\begin{array}{c}\text { (AlBedah } \\
\text { et al., } \\
\text { 2015) }\end{array}$ & $\begin{array}{c}\text { Randomi } \\
\text { zed } \\
\text { Controlle } \\
d \\
\text { Clinical } \\
\text { Trial }\end{array}$ & $\begin{array}{l}\text { Responden terdiri } \\
\text { dari pria dan wanita } \\
\text { dengan rentang usia } \\
18 \text { sampai } 60 \text { tahun. } \\
\text { Jumlah responden } \\
80 \text { orang secara } \\
\text { acak dialokasikan ke } \\
\text { dalam kelompok } \\
\text { intervensi }(n=40) \\
\text { dan kelompok } \\
\text { kontrol }(n=40) .\end{array}$ \\
\hline
\end{tabular}

yang sama diulangi untuk jumlah waktu yang sama di sisi kiri subjek Seluruh perawatan memakan waktu 20 menit untuk merawat kedua sisi tubuh.

Enam sesi bekam basah dalam 2 minggu, yang masing-masing dilakukan pada dua meridian kandung kemih (BL) titik akupunktur antara BL23, BL24, dan BL25. Pemberian asetaminofen maksimal tiga tablet asetaminofen $500 \mathrm{mg}$ perhari diizinkan untuk kedua kelompok, terapi alternatif, dan terapi fisik dilarang selama 4 minggu. secara signifikan

antara kedua

kelompok $(\mathrm{P}<0,001)$.

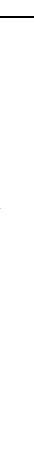

Hasil penelitian menunjukkan skore

NRS setelah 2 minggu

intervensi menurun pada kelompok intervensi dibandingkan kelompok control.

Pada minggu keempat intervensi menunjukkan penurunan NRS yang signifikan pada kelompok intervensi dibandingkan kelompok kontrol $(p=0.0001)$.

Setelah sesi

perawatan, kadar

kortisol plasma dan skor VAS menurun secara signifikan di kedua kelompok. Dalam kelompok akupunktur laser ditambah bekam Cina, skor VAS menurun secara signifikan pada hari ke-4 dan 5.

\begin{tabular}{ccc}
\hline (Lin et al., & Randomi & 48 pasien dengan \\
2017) & LBP non spesifik \\
Controlle & kronis. Pasien yang \\
& mengalami LBP non \\
& & spesifik kronis \\
& selama setidaknya 3 \\
bulan antara tulang & rusuk ke-12 dan \\
& lipatan gluteal \\
& disertakan. \\
& Pengacakan \\
& dilakukan setelah 48 \\
& pasien selesai \\
& menandatangani \\
& formulir persetujuan \\
& berdasarkan \\
& informasi.
\end{tabular}

Instrumen LLLT 4 saluran $808 \mathrm{~nm}$ LA400 (United Integrated Services Co., Ltd., Taiwan; daya keluaran, 40 $\mathrm{mW}$; frekuensi, $20 \mathrm{~Hz}$; siklus kerja, $50 \%$; dosis, $15 \mathrm{~J} / \mathrm{cm}^{2}$ ) dengan cahaya inframerah dekat digunakan. Laser akupuntur diterapkan pada titik akupuntur Weizhong (BL40) dari fossa poplitea dan titik akupuntur Ashi di otot punggung selama 10 menit. Setelah akupuntur laser, empat cangkir DongBang 6 $\mathrm{cm}$ digunakan untuk bekam Cina. Setelah cangkir ditempatkan di otot punggung bawah di tingkat L2-5 sendi tulang belakang lumbal, masing-masing cangkir menghisap sampai $1 \mathrm{~cm}$ dengan kulit ditarik dan kemudian ditahan selama 5 menit. Protokol pengobatan yang sama diikuti untuk kelompok kontrol; namun, pasien dalam kelompok ini menerima low-level laser therapy (LLLT) palsu selama akupunktur laser. Dokter (Lin M.

L.) memberikan pengobatan kepada semua orang pasien antara pukul 3 dan 6 sore (waktu aliran riang kandung kemih meridian) selama 5 hari terus menerus.

\begin{tabular}{cccc}
\hline 6 & (Stephens, & Randomi & Semua peserta \\
Selkow, \& & zed & secara acak \\
Hoffman, & Controlle & dialokasikan \\
& 2020) & $d$ & menjadi 3 \\
& & Clinical & Kelompok terdiri \\
& & Trial & dari (1) bekam \\
& & kering, (2) bekam \\
\hline
\end{tabular}




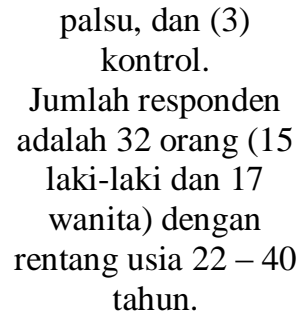

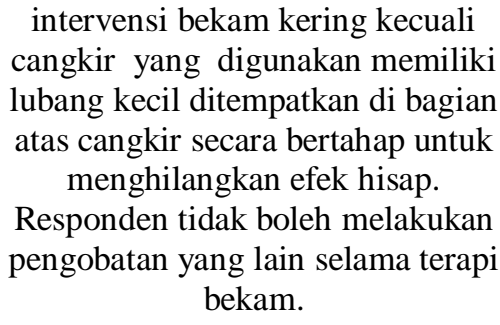
cangkir yang digunakan memiliki lubang kecil ditempatkan di bagian atas cangkir secara bertahap untuk menghilangkan efek hisap. Responden tidak boleh melakukan pengobatan yang lain selama terapi bekam.

\author{
bahwa kelompok \\ bekam kering \\ memiliki skala nyeri \\ lebih rendah \\ dibandingkan \\ kelompok bekam \\ palsu dan kelompok \\ kontrol.
}

\section{PEMBAHASAN}

Persamaan yang ditemukan pada artikel yang sudah ditelaah antara lain: pengacakan peserta dalam mendapatkan intervensi, peserta dibutakan dari intervensi yang diberikan, dan intervensi yang diberikan untuk mengetahui efektifitas dalam mengatasi nyeri (Rajin, M., 2020).

Perbedaan yang ditemukan pada artikel yang sudah ditelaah antara lain: jenis intervensi, waktu intervensi dan durasi intervensi. Intervensi yang digunakan adalah terapi bekam kering, bekam basah, dan akupuntur laser ditambah dengan bekam cina (Lin et al., 2017). Waktu intervensi tiap terapi diantaranya terapi bekam dilakukan 1 kali seminggu dan 2 kali seminggu (Teut et al., 2016). Durasi waktu saat melakukan bekam terdiri dari 10 menit dalam 1 kali terapi dan 8 menit dalam 1 kali terapi (Stephens et al., 2020).

Keterbatasan yang terdapat pada artikel yang sudah ditelaah adalah adanya titik bekam yang bermacam-macam sehingga mempengaruhi hasil penelitian, ukuran sampel yang kecil menjadi sebab adanya bias dari hasil penelitian.

Dari 6 artikel yang kami telaah, bekam yang paling efektif dalam mengurangi terjadinya nyeri yaitu terapi bekam pulsatil pada pasien dengan nyeri punggung bawah kronis yang setelah dilakukan intervensi selama 4 minggu tampak menunjukkan perbedaan efek yang signifikan dalam mengurangi nyeri (Teut et al., 2016).

Proses bekam dalam mengurangi nyeri punggung bawah dengan cara meraba daerah punggung yang akan dibekam terlebih dahulu dan kadar kortisol plasma dianalisis sebelum dan sesudah sesi pengobatan dan intensitas nyeri dicatat. Nyeri berkurang pada punggung pada titik BL40 sehingga meningkatkan QI dan sirkulasi darah dan mengurangi LBP sehingga dapat mengurangi nyeri pada punggung karena kadar kortisol plasma menurun (Lin et al., 2017) .

Bekam secara bertahap akan menyebabkan terangkatnya kulit di dalam gelas bekam karena sifat viskoelastik kulit dan menyebabkan terjadinya penekanan pada kulit di bagian tepi dari gelas bekam sehingga terjadi penurunan tekanan pada kulit yang terangkat tersebut. pada saat kulit terangkat secara bertahap maka akan mengurangi penyerapan pada ujung pembuluh darah vena dan kapiler. Akumulasi cairan yang yang mengandung toksin dan sel darah hemolitik akan menyebabkan delusi dan redistribusi mediator nosiseptor lokal seperti mediator inflamasi, mengurangi rangsangan prostaglandin. Hal ini bisa mengurangi neurotransmisi sensasi rasa sakit sehingga dapat menimbulkan efek analgesik yang dapat mengurangi sensasi nyeri saat laserasi pada kulit yang dilakukan bekam (Kalim et al., 2019).

Patofisiologi nyeri punggung bawah pada orang dengan kebiasaan merokok hal ini tidak diketahui secara signifikan namun terdapat salah satu teori yang menyatakan bahwa kandungan nikotin di dalam rokok dapat menyebabkan vasokonstriksi Pembuluh darah yang mensuplai nutrisi ke sel-sel diskus intervertebralis, jika nutrisi terganggu sel-sel akan mengalami malnutrisi yang menyebabkan mudah mengalami kerusakan. kandungan nikotin di dalam rokok dapat mengakibatkan penebalan dinding pembuluh darah nikotin mempunyai efek negatif terhadap sel osteoblas yaitu mempengaruhi proliferasi dan metabolisme seluler osteoblas dan sintesis kolagen, maka kepadatan mineral tulang akan berkurang. Salah satu akhir dari rokok adalah gas beracun karbon monoksida. Karbon Monoksida yang dihasilkan dari hasil pembakaran rokok akan berikatan dengan hemoglobin yang mengakibatkan penghambatan dan mengurangi pelepasan oksigen yang seharusnya diberikan dengan hemoglobin ke jaringan, terutama jaringan sel diskus intervertebralis yang yang kurang nutrisi. Faktor risiko yang secara statistika signifikan berkontribusi terhadap timbulnya nyeri punggung bawah di lingkungan kerja anestesiologi dan terapi intensif adalah faktor kurangnya olahraga, respon bagi seseorang yang kurang berolahraga akan memiliki kemungkinan 
untuk mengalami nyeri punggung bawah dibandingkan dengan orang yang sering berolahraga (Urits et al., 2019).

\section{KESIMPULAN}

Hasil literatur terhadap 6 artikel yang dilakukan penulis menunjukkan bahwa penggunaan terapi bekam memiliki efek positif yaitu dapat mengurangi skala nyeri dari 3 hingga 8 dan nyeri punggung bawah non-spesifik, mengurang intensitas nyeri VAS (visual analogue scale) mengurangi rasa sakit pada pasien nyeri leher, kadar kortisol plasma dan skor VAS menurun secara signifikan, memiliki sedikit efek samping, meningkatkan SST (skin surface temperature) dan mengurangi SBP (spontaneous bacterial peritonitis).

Kurangnya penelitian tentang terapi bekam di Indonesia menjadi sebuah tantangan penelitian selanjutnya, besarnya manfaat yang dibuktikan dari penggunaan terapi bekam dalam menangani skala nyeri pada pasien diharapkan mampu meningkatkan keinginan perawat menekuni terapi bekam serta dapat melanjutkan penelitian lebih lanjut di Indonesia. Kurangnya petugas kesehatan yang menekuni terapi bekam dapat menghambat aksesibilitas pelayanan kesehatan komplementer.

\section{UCAPAN TERIMA KASIH}

Penulis bersyukur selama penulisan artikel banyak mendapatkan bantuan moril dan materil dari rekanrekan angkatan dan staf dosen di institusi tempat penulis bekerja.

\section{REFERENSI}

AlBedah, A., Khalil, M., Elolemy, A., Hussein, A. A., AlQaed, M., Al Mudaiheem, A., ... Essa, A. (2015). The use of wet cupping for persistent nonspecific low back pain: randomized controlled clinical trial. The Journal of Alternative and Complementary Medicine, 21(8), 504-508.

Allegri, M., Montella, S., Salici, F., Valente, A., Marchesini, M., Compagnone, C., ... Fanelli, G. (2016). Mechanisms of low back pain: a guide for diagnosis and therapy. F1000Research, 5.

Cao, H., Han, M., Zhu, X., \& Liu, J. (2015). An overview of systematic reviews of clinical evidence for cupping therapy. Journal of Traditional Chinese Medical Sciences, 2(1), 3-10.

Chi, L.-M., Lin, L.-M., Chen, C.-L., Wang, S.-F., Lai, H.-L., \& Peng, T.-C. (2016). The effectiveness of cupping therapy on relieving chronic neck and shoulder pain: a randomized controlled trial. EvidenceBased Complementary and Alternative Medicine, 2016.

de Almeida Silva, H. J., Saragiotto, B. T., Silva, R. S., de Almeida Lins, C. A., \& de Souza, M. C. (2019). Dry cupping in the treatment of individuals with non-specific chronic low back pain: a protocol for a placebo-controlled, randomised, double-blind study. BMJ Open, 9(12), e032416.

Genebra, C. V. D. S., Maciel, N. M., Bento, T. P. F., Simeão, S. F. A. P., \& Vitta, A. De. (2017). Prevalence and factors associated with neck pain: a population-based study. Brazilian Journal of Physical Therapy, 21(4), 274-280. https://doi.org/https://doi.org/10.1016/j.bjpt.2017.05.005

Hartvigsen, J., Hancock, M. J., Kongsted, A., Louw, Q., Ferreira, M. L., Genevay, S., ... Sieper, J. (2018). What low back pain is and why we need to pay attention. The Lancet, 391(10137), 2356-2367.

Kalim, H., Wahono, C. S., Rahman, P. A., Najikhah, N. R., Santoso, A. A., Winoto, E. S., \& Jayanto, G. D. (2019). Reumatologi Klinik. Universitas Brawijaya Press.

Lin, M.-L., Wu, J.-H., Lin, C.-W., Su, C.-T., Wu, H.-C., Shih, Y.-S., .. Chang, W.-D. (2017). Clinical effects of laser acupuncture plus Chinese cupping on the pain and plasma cortisol levels in patients with chronic nonspecific lower back pain: a randomized controlled trial. Evidence-Based Complementary and Alternative Medicine, 2017.

Lindquist, R., Tracy, M. F., \& Snyder, M. (2018). Complementary \& alternative therapies in nursing. Springer Publishing Company.

Meucci, R. D., Fassa, A. G., \& Xavier Faria, N. M. (2015). Prevalence of chronic low back pain: Systematic review. Revista de Saude Publica, 49, 1-10. https://doi.org/10.1590/S00348910.2015049005874

Rajin, M. (2020). Buku Bahan Ajar Keperawatan Komplementer Terapi Akupunktur (1st ed.). Kediri: Chakra Brahmanda Lenter.

Righo, A., \& Ronas, M. R. (2014). Terapi Bekam Terbukti Mampu Mengatasi Hipertensi (1st ed.). Bandung: Rasi Terbit. 
Stephens, S. L., Selkow, N. M., \& Hoffman, N. L. (2020). Dry Cupping Therapy for Improving Nonspecific Neck Pain and Subcutaneous Hemodynamics. Journal of Athletic Training, 55(7), 682690.

Teut, M., Ullmann, A., Ortiz, M., Rotter, G., Binting, S., \& Brinkhaus, B. (2016). Cupping in chronic low back pain - A randomized three-armed partly-blinded clinical trial. European Journal of Integrative Medicine, 8, 2. https://doi.org/10.1016/j.eujim.2016.12.001

Teut, M., Ullmann, A., Ortiz, M., Rotter, G., Binting, S., Cree, M., ... Brinkhaus, B. (2018). Pulsatile dry cupping in chronic low back pain-a randomized three-armed controlled clinical trial. BMC Complementary and Alternative Medicine, 18(1), 1-9.

Urits, I., Burshtein, A., Sharma, M., Testa, L., Gold, P. A., Orhurhu, V., ... Spektor, B. (2019). Low back pain, a comprehensive review: pathophysiology, diagnosis, and treatment. Current Pain and Headache Reports, 23(3), 1-10.

Wu, A., March, L., Zheng, X., Huang, J., Wang, X., Zhao, J., ... Hoy, D. (2020). Global low back pain prevalence and years lived with disability from 1990 to 2017: estimates from the Global Burden of Disease Study 2017. Annals of Translational Medicine, 8(6), 299-299. https://doi.org/10.21037/atm.2020.02.175 